\title{
POLSKIE I BUŁGARSKIE UMOWY PRAWA CYWILNEGO JAKO TEKSTY MODELOWE I ICH ZASTOSOWANIE W DYDAKTYCE PRZEKŁADU
}

\begin{abstract}
Zarys treści: W niniejszym artykule zwracam uwagę na zastosowanie tekstów modelowych w dydaktyce przekładu, które ma na celu zwiększenie wiedzy metajęzykowej o zasadach budowy i spójności tekstów; zwiększenie wiedzy o mechanizmach językowych charakterystycznych dla danego typu tekstów (konwencja językowa) oraz refleksję nad zasadami redagowania tekstu (konwencja tekstowa). W nawiązaniu do powyższych założeń prezentuję wybrane zagadnienia z zakresu makro- i mikrostruktury umów prawa cywilnego funkcjonujących w Polsce i w Bułgarii. W skrócie omawiam organizację wewnętrzną tekstów, ich prezentację graficzną oraz elementy obowiązkowe i fakultatywne. Dokonując analizy kontrastywnej tekstów, koncentruję się zwłaszcza na ich warstwie językowej. Po pierwsze opisuję występujące w umowach czasowniki performatywne, po drugie omawiam słownictwo specjalistyczne w zakresie nazewnictwa umów oraz stron umowy w obu językach. Opisu modeli dokonuję ma podstawie korpusu tekstów obejmujący 24 typy umów dla każdego z języków.
\end{abstract}

$\dot{c}$ wiczenia na modelowych tekstach równoległych (tzw. tekstach prototypowych) stanowią niewątpliwie istotny element nauczania przekładu użytkowego. Właściwie zastosowane w procesie dydaktycznym pozwalają na rozwinięcie umiejętności autonomicznej pracy z zaproponowanym materiałem obserwacyjnym w postaci np. korpusu tekstów danego gatunku. Teksty te mogą być autentyczne lub paraautentyczne. Porównywanie różnego rodzaju realizacji danego typu tekstu zawodowego służy nie tylko znalezieniu wzoru czy modelu właściwego dla danego gatunku, ale ma pobudzać do refleksji nad mechanizmami tworzenia tego typu struktur. Szkoląc adeptów w zawodzie tłumacza, należy więc zwrócić uwagę na kilka ważnych punktów odniesienia. Powszechnie zalecana w nauczaniu przekładu użytkowego technika po- 
równywania tekstów w celu wyodrębnienia modelu nie polega, jak się często błędnie wydaje, jedynie na sprawnym imitowaniu tzw. wzorów (bowiem tzw. wzory pism i różnego rodzaju dokumentów są łatwo dostępne na stronach internetowych, w poradnikach i innych pozycjach). Natomiast ważnym elementem w dydaktyce jest taka praca $\mathrm{z}$ tekstem, która ma na celu:

1. zwiększenie wiedzy metajęzykowej o zasadach budowy i spójności tekstów,

2. zwiększenie wiedzy o mechanizmach językowych typowych/charakterystycznych dla danego typu tekstów (konwencja językowa),

3. refleksję nad zasadami redagowania tekstu (konwencja tekstowa).

W praktyce tłumaczeniowej często obcujemy z tekstami użytkowymi, którym przypisuje się stereotypową strukturę (por. Tomaszkiewicz 2003: 238). Do tekstów tego typu należy zaliczyć również umowy cywilnoprawne. Można je skutecznie wykorzystywać jako materiał glottodydaktyczny w pracy ze studentami w celu osiągnięcia wskazanych powyżej efektów kształcenia. Przygotowując studentów do analizy modelu, należy zwrócić uwagę na fakt, że są to teksty zdeterminowane ściśle określoną sytuacją komunikacyjną. Oprócz tego mają one stałe elementy treści, cechują się przezroczystą, odpowiednio uporządkowaną organizacją struktury wewnętrznej. W odpowiedzi na panujące współcześnie tendencje globalizacyjne zauważalne są dążenia do maksymalnego ujednolicania tego typu tekstów w celu ułatwienia komunikacji międzynarodowej. Tłumacz musi jednak pamiętać, że mimo wspólnej strategii komunikacyjnej, jaka przyświeca umowom, realizowane są one w różnych społeczeństwach. Jak udowadnia wiele badań kontrastywnych ${ }^{1}$, modele tekstów funkcjonujące na gruncie języków narodowych są silnie osadzone w danym kontekście kulturowym, a tym samym nie są identyczne. Kompetentny tłumacz ma świadomość podobieństw i różnic występujących między modelami w parze językowej, w której dokonuje przekładu.

Kilkuletnie doświadczenie w zakresie nauczania przekładu użytkowego wśród studentów poznańskiej bułgarystyki podpowiada mi, że jednym z priorytetowych celów nauczania podczas pracy z tekstem jest właśnie refleksja nad mechanizmami językowymi. Szczególnie przydatna w tym kontekście okazuje się koncepcja makro- i mikrostruktury tekstu. Dlatego w niniejszym artykule dokonuję właśnie oglądu makro- i mikrostruktury umów prawa cywilnego funkcjonujących w Polsce i w Bułgarii. W skrócie omawiam organizację wewnętrzną tekstów, ich prezentację graficzną oraz elemen-

${ }^{1}$ Mam na myśli na przykład następujące opracowania: Spillner 1981; Spillner 1983; Thiel, Thome 1987. 
ty obowiązkowe i fakultatywne. Dokonując analizy kontrastywnej tekstów, koncentruję się zwłaszcza na ich warstwie językowej. Po pierwsze opisuję występujące w umowach czasowniki performatywne, po drugie omawiam słownictwo specjalistyczne w zakresie nazewnictwa umów oraz stron umowy w obu językach. Opisu modeli dokonuję na podstawie korpusu tekstów obejmującego 24 typy umów dla każdego z języków. Są to umowy: agencyjna, cesji, darowizny, dostawy, dystrybucji, dzierżawy, komisu, konsygnacji, kupna-sprzedaży, leasingu, najmu, poręczenia, pożyczki, przewozu, składu, spedycji, sponsoringu, zamiany, zastawu, przedwstępna, zlecenie oraz o dzieło, o roboty budowlane, o pracę 2 .

\section{Organizacja wewnętrzna i prezentacja graficzna tekstu}

Makrostruktura umów polskich i bułgarskich charakteryzuje się kilkoma wyraźnymi właściwościami:

- nazwa umowy: zarówno teksty polskie, jak i bułgarskie zawierają tytuł w postaci nazwy umowy, np. Umowa agencyjna/Агентски договор, Umowa kupna-sprzedaży/Договор за покупко-продажба itp. Tytuł zawsze wyróżnia się na tle całości, tzn. może być pogrubiony, zapisany wielkimi literami, podkreślony, przeważnie wyśrodkowany itd.;

- podział tekstu: tekst umów jest zawsze wyraźnie podzielony na logiczne całości, co graficznie zostaje zasygnalizowane za pomocą paragrafów (tekst polski), punktów, podpunktów, artykułów /чл./ (tekst bułgarski). O ile w polskich kontraktach całość podzielona jest najczęściej na paragrafy, które mogą zawierać tytuły, o tyle w przypadku umów bułgarskich tekst dzieli się zazwyczaj na opatrzone tytułem punkty, dalej na podpunkty lub artykuły;

- data i miejsce: obligatoryjnym elementem każdej umowy jest wskazanie daty i miejsca jej sporządzenia. Zarówno w tekstach polskich, jak i bułgarskich informacje te są odnotowywane na początku;

- podpisy stron: u dołu umowy składane są podpisy umawiających się stron.

2 Pomysł przygotowania niniejszej analizy zrodził się z braku opracowań dydaktycznych w zakresie nauczania przekładu w parze językowej polski-bułgarski. W zamyśle zatem artykuł ma stanowić swego rodzaju pomoc dydaktyczną w pracy ze studentami. 


\section{Obligatoryjne elementy umowy}

W omawianych typach tekstów do informacji o charakterze obowiązkowym należą:

\section{Dane osobowe umawiających się stron}

\begin{tabular}{ll} 
Umowy polskie & Umowy bułgarskie \\
\hline Imię i nazwisko & Imię, patronimicum, nazwisko \\
Adres & Adres \\
Numer dowodu osobistego & Numer dowodu osobistego \\
Data wydania i organ wydający & Data wydania i organ wydający
\end{tabular}

$\mathrm{Na}$ podstawie przedstawionego porównania widoczna jest różnica w danych osobowych wynikająca $\mathrm{z}$ faktu, że Bułgarzy, w odróżnieniu od Polaków, posługują się trójczłonowym schematem nominacyjnym (mpume имена): imię własne + patronimicum + nazwisko (np. Камен Дъмитров Касабов).

Wskazane powyżej informacje mogą zostać poszerzone na przykład o unikatowy numer ewidencji ludności, w skrócie nazywany na gruncie polskim numerem PESEL (Powszechny Elektroniczny System Ewidencji Ludności) i na gruncie bułgarskim ЕГН (Единен граждански номер). Polskie i bułgarskie symbole numeryczne różnią się liczbą cyfr - numer PESEL jest 11-cyfrowy, ЕГH składa się z 10 cyfr. Przy tym struktura symbolu w obu wypadkach jest podobna, tzn. początkowych sześć cyfr, zarówno w numerze PESEL, jak i w EГH oznacza datę urodzenia (rok - miesiąc - dzień). W przypadku numeru PESEL cyfry od 7. do 10. oznaczają numer serii z oznaczeniem płci (10. - płeć), a 11. to cyfra kontrolna. W bułgarskim numerze ЕГН cyfry od 7. do 9. wskazują na region w Bułgarii z oznaczeniem płci (9. - płeć) i 10. to cyfra kontrolna.

W sytuacji gdy stroną w umowie jest podmiot gospodarczy, konieczne jest wskazanie następujących danych:

$\begin{array}{ll}\text { Umowa polska } & \text { Umowa bułgarska } \\ \text { Nazwa podmiotu } & \text { Nazwa podmiotu } \\ \text { Forma prawna prowadzonej działalności } & \text { Forma prawna prowadzonej działalności } \\ \text { Siedziba i adres firmy } & \text { Siedziba i adres firmy } \\ \text { Reprezentowana przez (dane osobowe) } & \text { Reprezentowana przez (dane osobowe) }\end{array}$

Oprócz tego dane firmy w odniesieniu do strony polskiej uwzględniają najczęściej również NIP oraz REGON. Analogiczne informacje mogą 
zostać zawarte w umowie bułgarskiej, tj. данъчен номер oraz единен идентификационен код БУЛСТАТ.

\section{Określenie przedmiotu umowy}

Jest to nieodzowny element wszystkich umów. W tej części umowy opisuje się przedmiot zobowiązania.

\section{Zobowiązania stron}

Obowiązkowym elementem umowy jest wskazanie praw i obowiązków umawiających się stron. Niekiedy informacje te zostają uwzględnione w części umowy traktującej o przedmiocie umowy. Najczęściej jednak zostają opisane w specjalnie wydzielonym fragmencie tekstu (paragrafie /pl/, punkcie /bg/).

\section{Informacje o charakterze metatekstowym}

Zarówno polskie, jak i bułgarskie kontrakty zawierają obowiązkowo informacje o charakterze metatekstowym, określające okoliczności sporządzenia i podpisania umowy. Należą do nich: data, miejsce, informacja o liczbie sporządzonych egzemplarzy (odpisów), podpisy stron, klauzula odsyłająca do stosownych przepisów.

Warto jednak zaznaczyć, że informacje o przepisach prawa regulujących sytuację zawarcia umowy charakteryzują się często różnym stopniem szczegółowości. W polskich umowach cywilnoprawnych spotykamy najczęściej klauzulę, która brzmi:

W sprawach nieuregulowanych postanowieniami niniejszej umowy zastosowanie maja przepisy Kodeksu cywilnego.

W bułgarskich kontraktach może wystąpić w tym miejscu informacja o takim samym poziomie szczegółowości:

За всички неуредени от настоящия договор положения се прилагат разпоредбите на Гражданския проиесуален кодекс и действащзото българско законодателство.

Tym niemniej najczęściej stosowana jest fraza o większym stopniu uogólnienia, zgodnie z którą „w sprawach nieuregulowanych postanowieniami danej umowy stosuje się przepisy prawa obowiązujące w Republice Bułgarii” / За неуредените в настоящия договор въпроси се прилагат разпоредбите на действащото в Република България законодателство/.

\section{Fakultatywne elementy umowy}

Poza wymienionymi powyżej elementami składowymi umowy mogą zawierać różne dodatkowe informacjie ogólne oraz charakterystyczne dla danego 
typu tekstów. I tak np. wiele zarówno polskich, jak i bułgarskich umów cywilnoprawnych uwzględnia takie elementy, jak: czas trwania umowy, warunki zmiany umowy, warunki wypowiedzenia lub zerwania umowy, ubezpieczenia przedmiotu umowy, ustalenia dotyczące płatności, tryb rozstrzygania sporów i inne, np. tzw. postanowienia ogólne lub końcowe. Oprócz tego poszczególne typy kontraktów mogą przybierać postać bardziej lub mniej rozbudowaną i przewidywać różne okoliczności. Do umów, które najczęściej występują w kontaktach Polaków z Bułgarami, należą niewątpliwie np. umowy przedwstępne kupna-sprzedaży nieruchomości czy umowy najmu. Postaram się przedstawić na przykładzie tego typu tekstu specyficzne dla niego elementy.

I tak np. zarówno polskie, jak i bułgarskie umowy przedwstępne kupna-sprzedaży nieruchomości najczęściej uwzględnią następujące treści: dane stron transakcji; określenie nieruchomości jako przedmiotu umowy; termin zawarcia umowy ostatecznej; uzgodnioną cenę; określenie sposobu realizacji płatności; opisanie zobowiązań umawiających się stron, które to zobowiązania muszą zostać wypełnione przed podpisaniem umowy ostatecznej; określenie wysokości zadatku. Na gruncie polskim i bułgarskim ostateczne umowy kupna-sprzedaży nieruchomości zawierane są w postaci aktu notarialnego.

W obu językach modelowe teksty umów najmu pokrywają się w znacznym stopniu. Do elementów wspólnych zarówno dla polskich, jak i bułgarskich kontraktów należą: dane stron transakcji, określenie przedmiotu naj$\mathrm{mu}$, przeznaczenie przedmiotu najmu (lokal mieszkalny, lokal użytkowy), wysokość czynszu, wskazanie wysokości kaucji, sposób płatności, opis stanu technicznego przedmiotu najmu, wskazanie kosztów dodatkowych z tytułu użytkowania lokalu (koszty zużywanej przez lokatorów energii elektrycznej, gazu, opłaty z tytułu zużywanej wody, odprowadzania ścieków oraz wywozu śmieci).

Ponadto umowy tego typu mogą zawierać wiele informacji dodatkowych odnośnie: terminowości wnoszenia opłat ( $w$ tym pierwszej daty wniesienia opłat), warunków zmiany wysokości czynszu, zobowiązania wynajmującego do przekazania najemcy przedmiotu najmu we właściwym stanie, zobowiązania najemcy do zdania przedmiotu najmu w nienaruszonym stanie, rozliczania kosztów i sposobu przeprowadzania remontu, zasad podnajmu i in.

Zasadnicza różnica między polskimi i bułgarskimi kontraktami polega na obowiązku zawarcia w polskim dokumencie deklaracji wynajmującego, że jest on właścicielem lokalu. Nie jest to natomiast obowiązkowy element bułgarskiej umowy najmu. 


\section{Warstwa językowa}

Umowy cywilnoprawne z punktu widzenia translatoryki są tekstami specjalistycznymi, które charakteryzuje wysoki stopień konwencjonalizacji zarówno na płaszczyźnie formy, jak i sposobu wyrażania treści. Tego typu oficjalne teksty prawniczne nasycone są terminologią oraz skostniałymi wyrażeniami idiomatycznymi (por. Tomaszkiewicz 2003: 243). W zakresie języka i polskie, i bułgarskie umowy cechuje:

1. Wyrażanie czynności za pomocą czasownika w 3. os. l. poj. lub mn.

Na samym początku strony umowy zostają nazwane określonym terminem, który to jest stosowany konsekwentnie w całym tekście, w rezultacie czego odnoszący się do czynności wykonywanych przez strony czasownik przybiera formę 3 os. l. poj. lub mn., np. pol. (strona umowy) zleca, dokona, wręcza, kwituje, przekazuje; (strony) ustalają, oświadczaja, że; bułg. (страна на договор) предава, възлага, възползва, плаща; (страните) се споразумяват.

2. Częste występowanie form bezosobowych czasownika oraz strony biernej, np. pol. zleceniodawca jest upoważniony do; najemca jest zobowiazany do; agent jest uprawniony do; umowa zostaje zawarta; wyroby zostana wydane; warunki sa określone; faktury będa płatne; towar zostanie przekazany; bułg. купувачьт е дльжен; плащането ще се извърии; договор се състави; изработката ще бъде реализирана; товаргт ще бъде превозван; искбт за вреди се погася.

3. Występowanie czasowników performatywnych

Jak wiadomo, „sednem wypowiedzi performatywnej jest to, że ma ona być wykonaniem jakiegoś działania (lub ma być włączona w nie jako jego część)" (Austin 1993: 606). Natomiast czasowniki nazywane performatywnymi „służą szczególnemu celowi wyraźnego ukazania (które nie jest tym samym, co stwierdzenie lub opisanie), czym dokładnie jest działanie, jakie zostaje wykonane przez wygłoszenie danej wypowiedzi" (Austin 1993: 607). Zważywszy na fakt jasno określonej sytuacji komunikacyjnej, w jakiej dochodzi do zawarcia umowy, tj. sytuacji zobowiązania się stron do wykonana lub zaniechania danych czynności, obecność czasowników performatywnych w tekstach kontraktów wydaje się oczywista. Najczęściej są to tzw. zobowiązaniowce. Wypowiedzi z ich udziałem „znamionuje obiecywanie czy branie na siebie odpowiedzialności w jakiś inny sposób” (Austin 1993: 695). Niewątpliwie sens zawierania umów cywilnoprawnych polega na zobowiązaniu umawiających się stron do przestrzegania określonego toku postępowania. Temu właśnie służą często powtarzane w kontraktach formy czasownika „zo- 
bowiązywać się", np. pol. zobowiązuje się do, jest zobowiązany do, będzie zobowiazany do; bułg. задължава се, е дльжен, е задължен, ще бъде длъжен. Do zobowiązaniowców należy zaliczyć deklaracje czy oświadczenia dotyczące zamiarów. Zarówno w polskich, jak i bułgarskich tekstach omawianych aktów prawnych występują w tej funkcji formy czasownika w czasie przyszłym, np. pol. zapłaci, uiści, zapewni, zakupi, zawrze (umowę), będzie udostępniał, będzie wypłacał, będzie prowadził; bułg. ще заплати, ще решават, ще натовари, ще покани, ще обезщети. Licznie poświadczone w tego typu tekstach modelowych są wypowiedzi sprawcze, np. z udziałem takich czasowników jak zezwalać, upoważniać, pobierać, zrzekać się, mieć prawo czy też wypowiedzi osądzające sygnalizowane za pomocą czasowników typu uznawać, rozumieć, ustalić wartość, obliczać i wiele innych.

4. Występowanie skostniałych wyrażeń idiomatycznych

Do wyrażeń tego typu należą odpowiadające sobie w obu językach typowe zwroty, np.

pol. nazywany dalej/bułg. наричан накратко, pol. legitymujący się dowodem osobistym/bułg. притежаваш, лична карта, w tym także kończące zazwyczaj kontrakt zdanie: pol. Umowe sporzadzono w dwu jednobrzmiacych egzemplarzach, po jednym dla każdej ze stron./bułg. Настоящият договор е съставен в два еднообразни екземпляра, по един за всяка от страните. Również częste w omawianym typie tekstów odsyłacze wewnątrz- czy też międzytekstowe przybierają formę skostniałych idiomów, np. pol. opisane $w$ pkt. 3 niniejszej umowy; zgodnie z postanowieniami niniejszej umowy; zgodnie ze wskazanymi wyżej warunkami; zgodnie z ustaleniami poczynionymi w dalszej części umowy; na podstawie ustawy; zgodnie z artykułem 3 Kodeksu cywilnego; bułg. съгласно член 3 от настоящия договор; съгласно клаузите на настоящия договор; съгласно правилата на раздел VII от настоящия договор; съгласно посочените по-горе изискванията; съгласно посочените вече условия; съгласно посочените понататьк условия; по реда начл. 37 от Търговски закон.

5. Nasycenie terminologią prawniczą

Teksty umów prawnych zawierają specyficzną terminologię. Analiza tekstów równoległych umożliwia sporządzenie listy występujących w danym typie umowy terminów oraz ich ekwiwalentów w języku docelowym. Jest to działanie zgoła różne od sięgania po słowniki specjalistyczne. Terminy specjalistyczne mogą mieć bowiem wiele odpowiedników w języku docelowym. Natomiast odwołanie się do słownictwa osadzonego w ściśle określonym kontekście pozwala ustalić właściwy, zazwyczaj jedyny ekwiwalent dla danego aktu prawnego. Dla przykładu prezentuję sporządzoną na podstawie ana- 
lizy porównawczej listę odpowiadających sobie terminów na gruncie języków polskiego i bułgarskiego, obejmującą nazwy umów oraz nazwy stron umowy.

\begin{tabular}{|c|c|}
\hline Umowa agencyjna & Агентски договор \\
\hline Zleceniodawca & Възложител \\
\hline Agent & Агент \\
\hline Umowa cesji & Договор за иесия \\
\hline Cedent & Цедент \\
\hline Cesjonariusz & Цесионер \\
\hline Umowa darowizny & Договор за дарение \\
\hline Darczyńca & Дарител \\
\hline Obdarowany & Надарен \\
\hline Umowa dostawy & Договор за доставка \\
\hline Odbiorca & Получател/Купувач \\
\hline Dostawca & Доставчик \\
\hline Umowa dystrybucji & Договор за дистрибуция \\
\hline Właściciel & Собственик \\
\hline Dystrybutor & Разпространител/Дистрибутор \\
\hline Umowa dzierżawy & Договор за аренда \\
\hline Wydzierżawiający & Арендодател \\
\hline Dzierżawca & Арендатор \\
\hline Umowa komisu & Комисионен договор \\
\hline Komitent & Комитент \\
\hline Komisant & Комисионер \\
\hline Umowa konsygnacji & Договор за продажба на консигнация \\
\hline Sprzedawca/Sprzedający & Продавач \\
\hline Konsygnator & Консигнатор \\
\hline Umowa kupna-sprzedaży & Договор за покупко-продажба \\
\hline Sprzedający/Sprzedawca & Продавач \\
\hline Kupujący/Nabywca & Купувач \\
\hline Umowa leasingu & Договор за лизинг \\
\hline Finansujący/Leasingodawca & Лизингодател \\
\hline Korzystający/Leasingobiorca & Лизингополучател \\
\hline Umowa пајти & Договор за наем \\
\hline Wynajmujący & Наемодател \\
\hline
\end{tabular}




\begin{tabular}{|c|c|}
\hline Najemca & Наемател \\
\hline Umowa o dzieło & Договор за изработка \\
\hline Zamawiajacy & Възложител \\
\hline Wykonawca & Изпьлнител \\
\hline Umowa o roboty budowlane & $\begin{array}{l}\text { Договор за извбршване на строителни } \\
\text { работи / Договор за изпвлнение на } \\
\text { строителни работи }\end{array}$ \\
\hline Inwestor/Zamawiający & Инвеститор/Възложител \\
\hline Wykonawca & Изпьлнител \\
\hline Umowa o prace & Трудов договор \\
\hline Pracodawca & Работодател \\
\hline Pracownik & Работник \\
\hline Umowa poręczenia & Договор за порбчителство \\
\hline Poręczyciel & Порғчител \\
\hline Wierzyciel/Dłużnik/Kredytobiorca & Кредитор \\
\hline Umowa pożyczki & Договор за заем \\
\hline Pożyczkodawca & Заемодател \\
\hline Pożyczkobiorca/Kredytobiorca & Заеметел \\
\hline Umowa przedwstępna & Предварителен договор \\
\hline Sprzedający/Sprzedawca & Продавач \\
\hline Kupujący/Nabywca & Купучач \\
\hline Umowa przewozu & Договор за превоз \\
\hline Przewoźnik & Превозвач \\
\hline Nadawca & Товародател \\
\hline Umowa składu & Договор за влог в публичен склад \\
\hline Składający & Влогодател \\
\hline Składowy & Влогоприемател \\
\hline Umowa spedycji & Спедиторски договор \\
\hline Spedytor & Спедитор \\
\hline Zleceniodawca & Доверител \\
\hline Umowa sponsoringu & Спонсорски договор \\
\hline Sponsor & Спонсор \\
\hline Sponsorowany & Спонсориран \\
\hline Umowa zamiany & Договор за замяна \\
\hline Zamieniający 1 & Първа страна \\
\hline
\end{tabular}




\begin{tabular}{|l|l|}
\hline Zamieniający 2 & Втора страна \\
\hline Umowa zastawu & Договор за залог \\
\hline Zastawnik & Залогодател \\
\hline Zastawca & Кредитор \\
\hline Umowa zlecenie & Договор за поръикa \\
\hline Zleceniodawca & Доверител \\
\hline Wykonawca & Довереник \\
\hline
\end{tabular}

\section{Zastosowanie prototypów tekstowych w dydaktyce przekładu}

Praca na modelowych tekstach równoległych stanowi niewątpliwie istotny element nauczania przekładu użytkowego. W procesie tłumaczenia umowy polskiej na język bułgarski i odwrotnie nie możemy traktować modelu jako sztywnego zbioru konwencji tekstowych. Niewątpliwie jednak analiza porównawcza omawianych aktów prawnych na gruncie języka źródłowego i docelowego dostarcza ważnej, z punktu widzenia autentyczności, ale i wierności przekładu, wiedzy specjalistycznej o właściwym zastosowaniu konwencji językowo-tekstowych w zależności od kontekstu sytuacyjnego. W takim rozumieniu teksty paralelne „pełnią rolę bardzo ważnych narzędzi translacyjnych oraz wzorców stylistycznych, frazeologicznych oraz terminologicznych” (Jędrzejowska 2009: 88). Praktyka przekładu nakazuje jednak pamiętać, że w odniesieniu do tekstów prawniczych zarówno w kształceniu tłumaczy, jak i w wykonywaniu tej profesji kwestie czysto terminologiczne i ogólnojęzykowe wydają się drugorzędne, o ile nie budzą wątpliwości, że użyty termin może wywoływać różne aniżeli implikowane tekstem źródłowym skutki prawne. Specyfika przekładu tego typu tekstów - nawet gdy mowa o stosunkowo niskim poziomie specjalizacji (jak w przypadku umów cywilnoprawnych) - polega na obowiązku „odtworzenia tego samego skutku prawnego, jaki jest implikowany przez akt normatywny kultury źródłowej” (Jędrzejowska 2009: 87).

\section{Literatura}

Austin Langshaw, J., 1993, Mówienie i poznanie, przeł. Bohdan Chwedeńczuk, PWN, Warszawa.

Jędrzejowska, I., 2009, „Specyfika przekładu tekstów prawnych a wybory tłumacza na przykładzie angielskich tłumaczeń tekstów ustaw”, [w]: Jakość 
i ocena tłumaczenia, A. Kopczyński, M. Kiezeweter (red.), Academica Wydawnictwo SWPS, Warszawa, s. 87-93.

Skalski, T., 2002, Sprawcza funkcja języka, Wydawnictwo UŁ, Łódź.

Spillner, B., 1981, Textsorten im Sprachvergleich. Ansätze zu einer kontrastiven Textologie, [w:] Kontrastive Linguistik und Übersetzungswissenschaft, W. Kühlwein, G. Thome, W. Wilss (red.), München, s. 239-250.

Spillner, B., 1983, „Zur kontrastiven Analyse von Fachtexten - am Beispiel der Syntax von Wetterberichten", LiLi. Zeitschrift für Literaturwissenschaft und Linguistik, 13, s. 110-123.

Šarčević, S., 1997, New Approach to Legal Translation, The Hague: Kluwer Law Interational.

Thiel, G., Thome, G., 1987, Resolutionen. Ein empirisch enwickelter Beitrag zur Textanalyse, Max Niemeyer Verlag, Tübingen.

Tomaszkiewicz, T., 2003, „Modele tekstów specjalistycznych a przekład”, [w]: Języki specjalistyczne. Zagadnienia dydaktyki i przekładu, P. Mamet (red.), Wydawnictwo Naukowe „Śląsk”, Katowice, s. 237-246.

\section{Polish and Bulgarian civil law contracts as statutory texts and their usage in translation didactics}

Summary

In this paper the author describes Polish and Bulgarian templates of civil law contracts and presents the following templates of texts: 1) internal organisation of texts and its graphical presentation, 2) obligatory and optional elements, 3) type of communication strategy chosen. To enable the comparative analysis of texts, a strong weighting towards its use in the language is recommended. Specific properties of legal texts include the following: identification of activities with the use of the thirdperson verb (singular or plural), frequent appearance of impersonal verb forms and passive voice, performative verbs, fixed idiomatic expressions, saturation with legal language. Textual properties are illustrated with corresponding examples in both languages. The author focuses particularly on translation difficulties which can occur in the translation process and emphasizes the need to use parallel texts in translation didactics. 